\title{
Social Dimension Analysis Script (SDAS): Descriptive Inventory for Problem Based Learning in Health Area
}

\author{
Lucimara Aparecida Faustino Custódio ${ }^{*}$ (i) , Camila Mugnai Vieira ${ }^{2}$, Ieda Francischetti², \\ Danielle Abdel Massih Pio², Tatiane Gomes Montes ${ }^{3}$, Karina Cicarelli1, \\ Alessandra Marlyn Silva Guimarães ${ }^{1}$, Renata Luciana Coneglian Facco \\ ${ }^{1}$ Student of the Professional Master’s Program in Health Education, Marília Medical School, Marília, Brazil
2Professor of Postgraduate Programs, Marília Medical School, Marília, Brazil
${ }^{3}$ Student of the Multiprofessional Integrated Residency in Health, Marília Medical School, Marília, Brazil
Email: `lu_faustino@famema.br, camilamugnai@gmail.com, iedafster@googlemail.com, danimassihpio@hotmail.com,
tatianegomesmontes95@gmail.com, kacicarelli@gmail.com, marlynalessandra@hotmail.com, renatalcfacco@gmail.com
}

How to cite this paper: Custódio, L. A. F., Vieira, C. M., Francischetti, I., Pio, D. A. M., Montes, T. G., Cicarelli, K., Guimarães, A. M. S., \& Facco, R. L. C. (2019). Social Dimension Analysis Script (SDAS): Descriptive Inventory for Problem Based Learning in Health Area. Creative Education, 10, 1091-1107. https://doi.org/10.4236/ce.2019.106082

Received: April 12, 2019

Accepted: June 9, 2019

Published: June 12, 2019

Copyright $\odot 2019$ by author(s) and Scientific Research Publishing Inc. This work is licensed under the Creative Commons Attribution International License (CC BY 4.0).

http://creativecommons.org/licenses/by/4.0/

\section{cc) (7) Open Access}

\begin{abstract}
This article describes the process of elaboration and use of a script in research for social dimension's analysis in the process of Problem Based Learning (PBL) in a course of health area. It is a descriptive inventory that was constructed based on previous studies and applied to analyze 69 problems or paper cases that trigger the teaching-learning process and their respective tutor guides which drive tutors of the first four medical years of a Brazilian public faculty. Documentary analysis of qualitative approach was carried out from a dense description. The script consisted of nine axes that characterized the profile of the characters and contexts of the problems, being: identification, space, competence area, health surveillance, living conditions (socio-environmental aspects and psychosocial aspects), access to health services, bonding, autonomy and diversities and vulnerabilities. The focus of this article is on the script itself and how it can guide the construction of problems and the detailed analysis of the social dimension in health courses whose curricula are mediated by the PBL.
\end{abstract}

\section{Keywords}

Medical Education, Curriculum, Problem Based Learning, Social Conditions, Social Determinants of Health

\section{Introduction}

Health is produced and influenced by the social context and, according to this 
perspective, health problems, as well as their aggravating and protective factors, must also be considered in their biopsychosocial aspects (Garbois, Sodré, \& Dalbello-Araujo, 2017).

Facing this intrinsic complexity of the health-disease process and the care, it is indispensable the formation of health professionals with a critical, reflective, humanist and ethical view, capable of articulating actions of promotion, prevention, care and rehabilitation, including the human being in its totality. These professionals should also be able to communicate in health's professional-patient relationship, as well as be prepared to act in the management of health services (Garbois et al., 2017; Mamede et al., 2001).

These attributes and abilities are not acquired naturally only by the passage of time and through work experience. These competences also depend on the educational process developed (Mamede et al., 2001).

To reach this understanding, social responsibility in Medical Education shows that the training process must transcend the knowledge and treatment of diseases, including the context of people's lives, as well as the social disparities and determinants of health, contributing to care equitable and integral (Thomas, 2014; Greer et al., 2018).

In pursuit of this professional profile, there is a worldwide transition from traditional methodologies based on knowledge transmission, memorization, compartmentalized disciplines without articulation and teacher-centered teaching, to innovative methodologies, based on an integrated curriculum and student-centered teaching, such as "Problem Based Learning" (PBL) (Campos, Aguiar, \& Belisário, 2012).

PBL emerged in the 1960s in Canada, at Mc Master's University in its Medical Course. Its philosophical basis is substantiated via action by experimentation and, second Dewey, meaningful learning occurs through reflection from live experience, through problems, situations that provoke imbalance, doubt, and unfamiliarity (Mamede et al., 2001). For Barrows and Tamblyn, this pedagogical model aims at the development of clinical reasoning and skills for self-training, stimulating the acquisition and integration of new knowledge (Barrows \& Tamblyn, 1980). PBL gained space in the context of social, health and epistemological transformations of the last 25 years of the 20th century (Mamede et al., 2001).

Thus, the cognitive basis of PBL has as its central focus the construction and apprehension of knowledge by the student, their active participation, their protagonism, and not the mere transmission of knowledge. The learning process in the PBL has characteristics and basic elements for its materialization such as: the problem, the tutorial group, the tutor, the individual study, small groups and the evaluation (Mamede et al., 2001).

The curriculum at PBL focuses on the use of problems, cases studies to provoke cognitive imbalance. This trigger will be better then more you can cross disciplinary boundaries and present situations and events integrated with a real context. In curriculum using PBL, the curricular elements are organized from 
compositions such as: organic, morpho-functional, modular, basic-clinical, life cycles, etc. (Mamede et al., 2001). In this sense, the problem is presented as the guiding thread of teaching-learning process in PBL and the more authentic the case and close to the real world, the more relevant and representative will be for the development of students learning. Because they are complex and situational, the problems will be solved mostly from the interdisciplinary perspective, sometimes being able to do so under the multiprofessional approach and understanding (Mamede et al., 2001; Aquilante, Silva, Avó, Gonçalves, \& Souza, 2011; Jonassen \& Hung, 2008).

The construction of problems is presented in form of cases, with the purpose of stimulating the learning in groups, activating the previous knowledge, enabling a contextualized learning, involving several disciplines, motivating the student to search for knowledge and understanding of the situation, leading to a solution that may be convergent or divergent. The construction of problems should stimulate students' cognitive growth throughout the course (Mamede et al., 2001; Aquilante et al., 2011).

For each problem available to students, a tutor's guide can be added, which contains, among other things, the specific objectives to be achieved during the tutorial process. The structure of the problem determines the proposed objectives and may favor meaningful learning (Mamede et al., 2001).

In accepting reality in its complexity, problems in PBL should locate the individual in their open, non-hermetic relational space and, in health, develop training for care of the same scope (Stewart et al., 2010). Considering the importance of the problem case and its nature, the following question emerged: How can you prepare meaningful problems that consider the context of people's lives? In order to answer this question, we analyzed all the problems and tutorial guides of a public medical school in the state of São Paulo, Brazil. Thus, it was necessary to develop a script for rolls' problem analysis that could serve as a basis for the construction of more complete and pedagogically more efficient problems.

Therefore, the objective of this paper is to present the method used to create an analysis tool, the Social Dimension Analysis Script (SDAS) built throughout dialectical analyze of paper problems used in PBL. The script was elaborated from the literature, illustrating results of current research, to bring the contribution to the processes of construction and analysis of the social dimension in health curricula that use the PBL.

This issue is organized in the following order: first shows how was the construction of the SDAS and after describes each of its nine axes as well as their respective elements. Then, the article discusses the SDAS's contributions and the study limitations.

\section{Method}

It is a documentary analysis (Silva, Almeida, \& Guindani, 2009), with a qualita- 
tive approach, in which the Content Analysis method was adopted (Bardin, 2012). As the delineation allowed to explain and clarify the question/problem, Clifford Geertz's (Geertz, 2017) thick description was used, whose task was to identify the meanings attributed to the social dimension expressed in institutional documents, enabling its description and apprehension of symbolic meanings and acts, of the written as well as the realized (Silva et al., 2009; Geertz, 2017).

The study scenario was a public college, in São Paulo's state, in Brazil, where PBL is used in Systematized Educational Unit, which occurs from 1st to 4th year of medical course.

The SDAS was developed by the researchers, based on Brazilian studies and legislation related to local health problems and the current training of physicians in the country. The study of Barros and Lourenço (Barros \& Lourenço, 2006) was based on the theoretical references: Health Needs (Cecílio, 2009), Social Determinants of Health (Garbois et al., 2017) and the National Curriculum Guidelines for medical course (Resolução CNE/CES n 3 de junho de 2014).

After reading the references, a framework was created with key terms and axes corresponding to social dimension, to which concepts were added on the subject addressed, to develop a detailed description of the materials studied. From the bibliographical survey, in order to better approximate the diversity of problem situations used in a medical course by PBL, and thus better refine the central axes for the construction and analysis of a relevant problem, we have exhaustively read out 69 problems from 1st to 4 th medical's years and their respective tutorial guides.

These problems are paper cases with diverse structures, some report stories of health situations in different complexity level, student conversation, lifestyles description, media news, some with exams other not.

The analysis of investigated literature, problems and guides were made, through Content Analysis, in thematic modality, followed the stages of pre-analysis, in which central ideas were systematized; material exploration, which consisted in codification and transformation of the data into thematic contents; and contents treatment and analysis, which was proposed by inference and interpretations based on theoretical presuppositions of the investigated references (Bardin, 2012). It resulted in a table containing two columns, the first with the keywords and the second with the sense cores. These themes were dialogued with literature and had their theoretical foundation based on their relevance to person's quality of life and health needs. Then, there were listed 9 important axes for health care.

\section{Results and Discussion}

The professionals' training, contextualized with reality, focused on promotion, prevention, rehabilitation and study of social context led to the creation of SDAS, a descriptive inventory with elements corresponding to social dimension for evaluation and construction of problems in PBL. 
Social Dimension Analysis Script (SDAS) consists of nine axes that characterize the profile of characters and contexts of the problems, being presented in Table 10. Each axis presents some elements that can be approached in PBL's problems and cases in courses for health area. Obviously, other elements can be included and these should be organized over courses' years and grades, according to their degree of complexity and the desired competence in each moment of training.

Next, we present the description and detail of axes and elements of social dimension that compose the Social Dimension Analysis Script (SDAS), discussing each axis with the current literature. It can be seen that some elements may be specific to Brazilian reality, but can be easily adapted for use in different contexts, since they refer to aspects common to health and human relations. Other elements can still be included depending on the desired competence at each point in training.

\subsection{Identification}

Refers to recognition and/or localization of demographic and socioeconomic data regarding the peculiarities of individuals, externalizing and preserving their identity. It is assumed that people are subjects of problems, and it is important to qualify their position and social condition (Barros \& Lourenço, 2006; Souza \& Ciampa, 2017).

The elements that can be approached in this axis, which refers to the characterization of the subjects, are presented in Table 1.

Space: refers to the territory and its specificities, which represent social, cultural and territorial identity of people. It indicates the space where social, power, cultural, political and economic relations are materialized, as well as the networks of relationships formed by the local morbidity and mortality factors. It corresponds to the conjuncture, structure, network of services, modes of production, represented by diversity, plurality and by social and individual conditions to which individuals are subjected (Política Nacional de Assistência Social, Brasil, 2005; Jaramillo, 2018; Barros \& Lourenço, 2006).

The elements that can be addressed in this axis, which refers to the characterization of contexts, are presented in Table 2.

Areas of competence: Ability to mobilize cognitive, affective and psychomotor attributes that allow approaching/solving complex situations related to professional practice, learning to observe the problem. Refers to reading and qualified professional responses determined by knowledge, skills, attitudes, articulated to individual and collective needs and management in health area, respecting and valuing the individual in its entirety (Faculdade de Medicina de Marília, 2014; Lima, 2005).

The elements that can be addressed in this axis, which refers to the characterization of the context, are presented in Table 3.

Health surveillance: A set of interdisciplinary actions, through articulated 
and intersectoral practices in development of promotion, prevention, care and rehabilitation actions, seeking improvements in living conditions and health protection. Emphasis on health problems, that require continuous attention and monitoring, as well as actions on the territory (Teixeira et al., 2000; Faculdade de Medicina de Marília, 2014).

Table 1. Identification axis of Social Dimension Analysis Script (SDAS) and its elements: age, gender, ethnicity, religion, marital status, schooling, profession, naturalness and provenance.

Age: represents the individual characteristic, as well as composes the set of elements of the intermediate determinants of health. Relative to the stage of life cycle, a means of understanding social phenomena related to age groups, as well as the set of laws that encompass each age group, ensuring their corresponding rights. (Garbois et al., 2017)

Ethnicity: presents the ethnic, racial and cultural diversity of social groups that constitute society in recognition and respect for differences. (Garnelo \& Pontes, 2012)

Marital status: characterizes the situation of personal and affective bonding among individuals, designates the individualization of social insertion and the individual role in the family and in the State that affect lifestyle and social conditions. (Garbois et al., 2017; Segheto et al., 2018; Fontes et al., 2017; Minayo, Figueiredo, \& Mangas, 2017)

Profession: comprise the set of structural determinants of health inequalities in which populations are stratified according to their occupation and income. It is related to the technical capacity, vocational choice, source of income, performance of functions, daily routine, career and professional identity, labor force, overload, stress and interpersonal relationships at work, work activity and/or inactivity, psychosocial development that reflects the individual's condition in social context. (Garbois et al., 2017; Rabelo, Silva e Lima, 2018; Torres, Camargo, Boulsfield, \& Silva, 2015)
Gender: it represents the individual characteristic, as well as composes the set of structural determinants of health inequalities. Gender is related to identity, social roles and image of social construction of feminine and masculine identities produced in historical and social context, guided by cultural particularities and not by biological and physical aspects only. (Garbois et al., 2017; Souza, 2014)

Religion: concerning to religious practices, beliefs, values, faith, spirituality, religious feeling. A major, transcendental force that embraces sociocultural diversity that permeates humanity. Something that characterizes the human being in social life and in various issues and actions, including the denial of spirituality, religiosity and/or religion. (Toniol, 2017)

Schooling: regarding access to education, level of schooling, processes of learning, teaching, values, literacy, socialization in school. It corresponds to the legitimation of social laws in teaching learning process that, through education, transmits knowledge, culture and can promote emancipation, resulting social changes. It represents one of the factors related to living and working conditions, as well as composing the set of structural determinants of health inequalities. (Garbois et al., 2017; Freire, 2015)

Naturalness and Provenance: characterizes the person's place of birth. (Garbois et al., 2017; Barros \& Lourenço, 2006) 
Table 2. Space axis of Social Dimension Analysis Script (SDAS) and its elements: territory, location, risk areas, social support equipment, intersectoriality, teaching/service integration.

Territory: presents characteristics and/or contexts of domiciles and the region, delimited space, social, cultural, epidemiological, political, economic, demographic, social relations establishments, as well as daily life elements, approximation of reality, health actions. (Brasil, 2005; Jaramillo, 2018; Teixeira, Paim, \& Vilasbôas, 2000)

Risk Areas: it is a defined geographic space, whose social, demographic and ecological conditions are liable to the occurrence of unfavorable events, natural or not, that generate damages, threats or dangers, as well as a physical space marked by social and territorial inequality, where situations of risk and vulnerability occur. (Brasil, 2005; Sampaio, Guimarães, \& Sampaio, 2013)

Intersectoriality: Integration of policies, aiming at action in social determinants. Concerning the partnership, cooperation and articulation of policies and services of the health network with complementary actions in view of the complexity that involves

health/illness/care processes, considering the integrality of the individual, health promotion, as well as individual and collective needs. (Cecílio \& Matsumoto, 2006)

Table 3. Areas of competence axis of Social Dimension Analysis Script (SDAS) and its elements: individual care, collective care, organization and management of health work.

Individual care: It restricts the possibility of intervention in individual need and demand, identifies, acts, elaborates, accompanies and evaluates the intervention plan. (Faculdade de Medicina de Marília, 2014; Lima, 2005; Faculdade Medicina de Marília, 2012)

Collective care: Opens possibilities for intervention in identification of public health policies, recognition of the territory, elaboration of epidemiological diagnosis and identification of the importance of social network in health/illness process, individual and collective care. (Faculdade de Medicina de Marília, 2014; Lima, 2005; Faculdade Medicina de Marília, 2012)

Organization and management of health work: It includes elements of organization and work process, health care management, teamwork, access and structure of services networks, encompasses policies and practices capable of organizing and managing actions that meet the individual and collective needs and demands, integral care. (Faculdade de Medicina de Marília, 2014; Lima, 2005; Faculdade Medicina de Marília, 2012)

The elements that can be addressed in this axis, which refers to the characterization of the contexts, are presented in Table 4.

Living conditions: Expresses health needs, individual and collective demands in responses to lifestyles and work influenced by social, economic, cultural, psychological, behavioral, psychosocial, ethnic, political, material circumstances, etc., which establish a relationship with the quality of life, work, health and 
people's behavior (Garbois et al., 2017; Cecílio, 2009).

The elements that can be addressed in this axis, which refers to the characterization of contexts, are presented in Table 5 .

Access to health services: The need to have access and be able to consume health technology, capable of improving and prolonging life. These technologies are to acceptance, hospitalization, therapeutic, as well as diagnostic and imaging tests. Access to the set of available technologies will be in accordance with the individual and collective needs expressed in provision of health services (Cecílio, 2009).

The elements of social dimension addressed in this axis, which refers to the characterization of contexts, are presented in Table 6.

Bonding: Corresponds to the constitution of the link between the user, the team and/or professional in a relationship of reference and trust. An essential device for establishing and strengthening relationships among the actors involved in the health/illness/care process, contributing to the users' access to health actions and services, in a humanized way. It is influenced by such factors as communication, empathy and professional ethics (Cecílio, 2009).

The elements of social dimension that can be addressed in this axis, which refers to the characterization of contexts, are presented in Table 7 .

Autonomy: Regarding the freedom people need to lead their lives. Health information and education are elements of this construction process. It refers to the ability of the individual and/or social groups to minister and manage life, made possible by decision-making in the exercise of freedom (Cecílio, 2009).

The elements of social dimension addressed in this axis, which refers to the characterization of contexts, are presented in Table 8.

Diversities and vulnerabilities: Refers to the pluralities and fragilities determined by physical factors; economic; social; life cycles; fragility of bonds of affectivity, belonging and sociability; ethnic, cultural or gender stigmatized identities; handicap resulting from disabilities; use of psychoactive substances; different forms of violence from the family nucleus, groups and individuals. They represent the characteristics and social aspects related to condition of life and personal situation that favor exclusion (Brasil, 2005; Barroco, 2016; Siqueira \& Castro, 2017).

The elements of social dimension addressed in this axis, which refers to the characterization of contexts, are presented in Table 9.

Table 4. Health surveillance axis of Social Dimension Analysis Script (SDAS) and its elements: promotion action, prevention action, assistance action, rehabilitation action.

Promotion action: regarding to actions that seek quality improvements in living and working conditions. (Teixeira et al., 2000)

Assistance action: concerning actions of assistance, diagnosis and treatment of diseases. (Teixeira et al., 2000)
Prevention action: regarding actions to prevent risks, injuries and diseases. (Teixeira et al., 2000)

Rehabilitation action: concerning the actions of recovery and rehabilitation of undermined functions. (Teixeira et al., 2000) 
Table 5. Living conditions axis of Social Dimension Analysis Script (SDAS) and its elements: socio-environmental aspects (living conditions and daily habits; income, benefits, retirement; financial aspects; hygiene/care; environment) and psychosocial aspects (religion/spirituality; structure/dynamics and family relationships; psychiatric disorders; mental, psychological and life cycle phases; social support; elements of mental state and conflicts, losses, separations, situations of stress, death, mourning).

\section{SOCIO-ENVIRONMENTAL ASPECTS:}

set of basic and fundamental elements that compose social life, which preserve the integrity of the person as:

Living conditions and daily habits: feeding, schooling, leisure, physical activity, living conditions, access to information, employment/work.

Income, benefits, retirement: sources of income to provide for subsistence, structural determinants of health inequalities, access to programs, services and assets of social laws, determinant factor and conditioning health levels. (Garbois et al., 2017; Lei n 8.080 de 19 de setembro de 1990, 1990)

Financial aspects: regarding the purchasing power of goods and services to provide basic needs and other demands, good living conditions. (Garbois et al., 2017; Cecílio, 2009)

Hygiene/care: regarding personal and life habits. Cleaning the environment and self-care. (Garbois et al., 2017; Cecílio, 2009)

Environment: environmental health actions that include: identification and characterization of health risk factors originated in environment; planning actions to prevent and promote health; control and surveillance actions and environmental education. Regarding the external and internal factors of living and working conditions, access to environmental health policies, services and goods, determining factor and conditioning of health levels. (Lei n 8.080 de 19 de setembro de 1990, 1990; Mota, 2013)

\section{PSYCHOSOCIAL ASPECTS:}

elements that compose social life, social relationships, mental state, support in social context, stressful factors, affectivity and human behavior as:

Religion/spirituality: they compose social and community networks, these networks of solidarity and trust between people and groups that, in addition to religious practices, play a fundamental role as a tool of care, social support, as well as help changes in lifestyle. (Brasileiro et al., 2017; Zerbetto et al., 2017)

Structure/dynamics and family relationships: reflect health and life conditions, social position regarding responsibility for home, autonomy and income. Regarding affective and interdependent relationships, plurality of family arrangements and structures, family relations by consanguineous bonds and/or affectivity, marital or marital connection between two persons of the opposite gender and/or the same gender. It encompasses conflicts, separations, crises and confrontations related to family. (Acosta \& Vitale, 2015; Sales, Matos, \& Leal, 2015)

Psychiatric disorders: they are psychic grievances, may be predominantly biological, psychological and social basis, are generally chronic, high prevalence, with social impact relevant to public health. Regarding emotional experiences, symptoms and sufferings related to mental health, which can be framed in psychiatric and/or. Examples of psychiatric disorders: depression, anxiety, mood and personality disorders psychodynamic diagnosis, eating disorders, psychotic disorders such as schizophrenia, obsessive-compulsive disorder, alcohol dependence and/or other drugs. Access to available policies and services, therapeutic resources, family and affective relationships, repercussions on life, social insertion. (Sampaio, Guimarães, \& Sampaio, 2013)

Mental, psychological and life cycle phases: refers to human psychodynamics and different moments of life, marked by diverse conflicts and learning. According to psychoanalysis, constituent elements, such as id, ego and superego, unconscious psychic determinism, ego defense mechanisms, such as compensation, denial, identification, rationalization, etc., their manifestations and repercussions for subjects and their life. It can also encompass the psychosexual developmental stages of the subjects (Freud, 2005). For other psychological approaches, such as Behavior Analysis, actions, verbal and non-verbal behaviors, relationships with the environment, promote reinforcing or punitive consequences, increasing the chances of behaviors occurring again (Skinner, 1953). 


\section{Continued}

According to other psychological approaches, it can refer to human subjectivity, identity, processes of internalization of culture, sense of self, constitution of personality, among others. There is also the possibility of approaching specificities of life cycle phases, such as childhood, adolescence, adulthood and senility.

Social support: concerning relationships of solidarity and trust between groups and people, contact with friends and relatives, forms of social participation and establishment of links. They contribute to health care. E.g.: participate in religious groups; neighborhood association; share experiences; trust in neighbors, etc. (Garbois et al., 2017; Barros \& Lourenço, 2006; Cecílio, 2009)

Elements of Mental State: regarding aspects that constitute the human being, being affected by external and internal agents, such as genetics, interpersonal relationships and environmental conditions. They need to be evaluated for better linkage, communication, diagnosis and treatment. Related to the appearance, behavior, thoughts and feelings of people, and may indicate or not, changes at different levels and/or mental disorders. Among them are: consciousness, memory, clothing, posture, orientation, humor, affection, language, intelligence, thought, volition, critical judgment, sense-perception, etc. (Andreasen \& Black, 2008)

Conflicts, losses, separations, situations of stress, death, mourning: Several experiences of situations triggering conflicts and mobilize affections, with repercussions in life of the individuals and their health, such as job losses, divorce, changes, fights and about death and dying, situations of lossing loved ones, serious diagnosis, terminal illnesses, sudden deaths and the grieving process experienced.

Table 6. Access to health services axis of Social Dimension Analysis Script (SDAS) and its elements: exams, medication, basic network, secondary network, tertiary network, emergency mobile service, specialties consultations, access to information/health education and accessibility.

Exams: demand for access to Medication: demand for access to the prescription and procedures, diagnostic exams that help medication available in public service network and/or by identify the health condition. (Lei ${ }^{\circ} \quad$ other means. May include self-medication. (Lei $n^{\circ} 8.080$ de 8.080 de 19 de setembro de 1990, 1990) 19 de setembro de 1990, 1990)

Basic network: access to basic care, low Secondary network: access to specialized and outpatient complexity gateway, health care. (Lei ${ }^{\circ}{ }^{\circ}$ services of medium complexity, health care. (Lei ${ }^{\circ} 8.080$ 8.080 de 19 de setembro de 1990,1990$)$ de 19 de setembro de 1990, 1990)

Tertiary network: access to high complexity hospital services, health care. (Lei $n^{\circ} 8.080$ de 19 de setembro de 1990,1990$)$
Emergency mobile service: access to the pre-hospital service that provides care to people in urgent and emergency situations. E.g.: Basic and Advanced Support Unit, Rescue, Fire Department. (Lei n ${ }^{\circ} 8.080$ de 19 de setembro de 1990, 1990)

Specialties consultations: demand for Access to information/health education: access to access to specialized care according to guidance, information, knowledge. Emancipation, right to health needs, multiprofessional team. receive guidelines on clinical conditions, treatment, (Lei $n^{\circ} 8.080$ de 19 de setembro de 1990,prognosis and other aspects related to health. (Lei $n^{\circ} 8.080$ 1990) de 19 de setembro de 1990, 1990)

Accessibility: several socio-cultural, economic, organizational, geographical, factors, etc., which may contribute to reduction of health care. Refers to the conditions and/or limitations and barriers that allow, hinder or prevent access to goods and services. Ensuring rights and health care with equity to all who need it. (Portaria $n^{\circ}$ 793, de 24 de abril de 2012, 2012; Missel, Costa, \& Sanfelice, 2017) 
Table 7. Bonding axis of Social Dimension Analysis Script (SDAS) and its elements: communication, ethics, empathy/solidarity/alterity, qualified listening and adherence to treatment.

Communication: relationship between patient and Ethics: Actions based on values; facts; health professional, marked by verbal and nonverbal language, dialogue, acceptance, autonomy; knowledge; etc. These are values techniques and attitudes that facilitate or hinder mutual understanding and bonding. It should include the Communication of Bad News in Medicine, such as communicating difficult diagnosis and prognoses to patients and family and rules of conduct established by society for collective coexistence, with respect for life, good and respect for the right of all. Professional ethics are governed by specific codes, supervised by councils. It covers professional confidentiality, contact with members, as well as reporting death. (Cecílio, 2009; Resolução CNE/CES n ${ }^{\circ} 3$ de junho de 2014, 2014) patients, varied conducts in decision-making situations, treatment of information provided and records, etc. (Resolução CNE/CES n ${ }^{\circ} 3$ de junho de 2014, 2014; Zanella, 2018)

Empathy/solidarity/alterity: strengthening the Qualified listening: commitment and concern construction of bond, putting oneself in the place of the other, sensitivity to understand the to make the best possible listening of health needs, listen carefully to the motives, experience of others, in order to respect it, to have initiative of cooperation and help the other. complaints and extended history, valuing the patient's report. (Cecílio, 2009)

(Cecílio, 2009; Resolução CNE/CES n 3 de junho de 2014, 2014)

Adherence to treatment: This is the most or less receptive behavior of the patient in relation to what is proposed by the professional, reflecting on his behaviors related to lifestyle, medication and indicated procedures. It depends on five dimensions: health system, disease, treatment of patients and factors related to caregiver (World Health Organization, 2003). Refers to the consent established in health professional/patient relationship provided by the information and clarification of the hypotheses, considering doubts and questions of the person under care and family and sharing the therapeutic process. (Cecílio, 2009; Resolução CNE/CES nº 3 de junho de 2014, 2014)

Table 8. Autonomy axis of Social Dimension Analysis Script (SDAS) and its elements: citizenship and social participation, mobility, dependence $\mathrm{X}$ independence and media and social networks.

\begin{tabular}{|c|c|}
\hline $\begin{array}{l}\text { Citizenship and social participation: active } \\
\text { presence in decision-making spaces, as well as } \\
\text { exercise of rights, fulfillment of duties and social } \\
\text { control. A broader understanding and appreciation } \\
\text { of collectivity, respect for common goods. It } \\
\text { depends on the educational and cultural process. } \\
\text { (Bonin, 2008) }\end{array}$ & $\begin{array}{l}\text { Mobility: Capacity of locomotion that } \\
\text { increase survival and quality of life. Access } \\
\text { to policies, services and goods, considering } \\
\text { respect for differences between citizens. } \\
\text { (Cecílio \& Matsumoto, 2006) }\end{array}$ \\
\hline $\begin{array}{l}\text { Dependence X Independence: it refers to the } \\
\text { inability and ability to maintain the autonomy of } \\
\text { the individuals of their own lives, as well as the right } \\
\text { and conditions for this to be effective. (Cecílio \& } \\
\text { Matsumoto, 2006) }\end{array}$ & $\begin{array}{l}\text { Media and social networks: access to media } \\
\text { and information, contribution to knowledge, } \\
\text { health improvements, contact with family } \\
\text { and professionals, and may have a positive } \\
\text { and/or negative impact. (Garbois et al., 2017; } \\
\text { Cecílio \& Matsumoto, 2006) }\end{array}$ \\
\hline
\end{tabular}


Table 9. Diversities and vulnerabilities axis of Social Dimension Analysis Script (SDAS) and its elements: prejudice and discrimination, racism, violence, vulnerable groups and social minorities and cultural diversity.

Prejudice and discrimination: includes Racism: it is based on discriminatory and prejudiced any opinion, unfair or negative treatment attitudes without scientific basis that assign hierarchy of a group or a person, based on judgment in various manifestations of systematic racial habits. (Barroco, 2016) discrimination of individuals belonging to social groups identified by physical and/or cultural traits. (Rocha, 2016)

Violence: involves violent or subtle acts, Vulnerable groups and social minorities: they are with the use of physical force and power, informed by people and/or groups that, due to lack of threat or in practice, against oneself, another person or against a group or representativeness, live at risk. Vulnerable groups seek to exercise their rights in face of social inequalities in community that results in or may result in society; minorities seek to conquer rights in face of the breach of mutual respect, suffering, cultural, social and ethnic inequalities, as well as their death, psychological damage, impaired exercise. E.g.: indigenous populations, people with development or deprivation. (World disabilities, elderly, blacks, women, refugees, Health Organization, 1996) homosexuals, transsexuals, etc. (Siqueira \& Castro, 2017)

Cultural diversity: represents the plurality and integration of the different cultures existing in human's relationship field. (Rückert, Cunha, \& Modena, 2018; Cavalcante, 2006)

\subsection{Use of Social Dimension Analysis Script (SDAS) in Problem Analysis and Tutoring Guides for a Medical Course}

The results related to characterization of the characters evidenced information deficits. Fundamental data such as age, ethnicity, schooling, religion, marital status and profession, which construct the individual's identity and interfere with health/disease process, were omitted in several situations.

In addition, several elements did not impact reality. The results on the characterization of contexts explained in several situations did not correspond to the real territory, since the areas of risks were poorly explored in their characteristics, recognizing their limits and potentialities. Social equipment and intersectoriality were little activated in attendance the health needs in search for integral care. These information gaps can interfere in representation of social dimension by compromising logical reasoning and the integration of this dimension into the others that comprise integrality of the individual and therefore the integral approach to care practices.

It should be noted that Social Dimension Analysis Script (SDAS) has proved to be a powerful instrument for identifying the necessary elements, qualifying them, organizing the data, indicating the feasibility and potential for use in other studies that intend to characterize and analyze the social dimension in curricula as well as in the process of elaborating problems, as guiding the axes and important elements for training in health area.

The instrument allows the organization of content, performances, activities (depending on the curriculum proposal) in order to visualize at what time of the courses, in which scenarios and/or triggers each theme is being worked out with the students, so, in their training relevant issues are addressed more integrally, in a more comprehensive way, and curriculum management is facilitated. 
The complete Social Dimension Analysis Script (SDAS) is shown in Table 10.

Table 10. Social Dimension Analysis Script (SDAS).

Identification Full name/Age/Schooling/Ethnic/Sex/Gender/Profession/Naturalness and Provenance /Religion/Marital status.

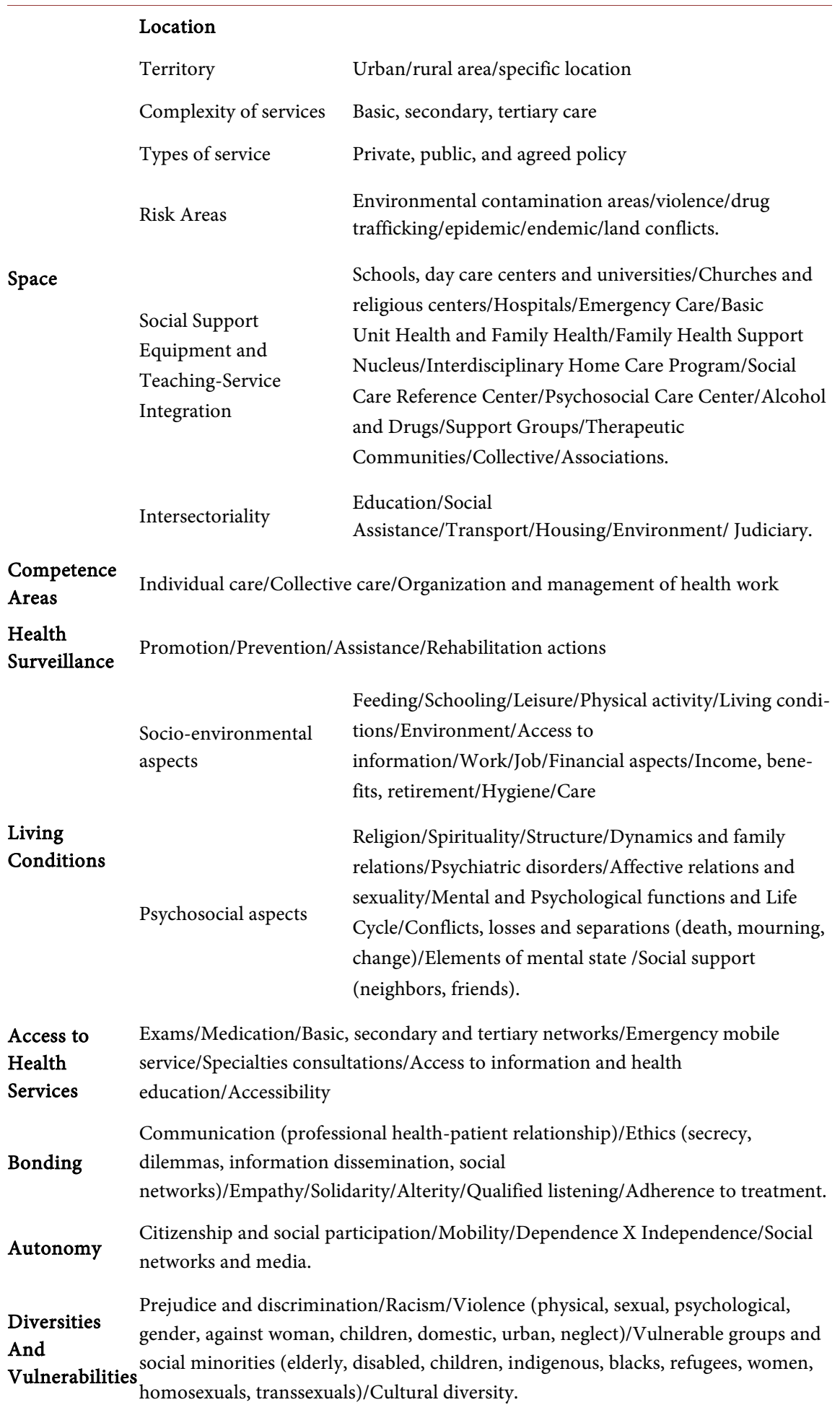




\section{Conclusion}

This study is the beginning of a reflection to better integrate the social dimension in PBL problems. The originality of this whole material is especially due to the creation of the script, a descriptive inventory of the elements corresponding to this social dimension. An investigation of this nature is configured as an in-depth study of the observed reality. Thus, Social Dimension Analysis Script (SDAS), the descriptive inventory, the fruit of this study, as well as the detailed description of each of its axes and elements can contribute to the evaluation of social dimension present in problems of curricula that use PBL, as well as the construction of new cases and problems, being able to serve as a guiding for elements to be inserted in the Curricular Matrix of Pedagogical Projects for Courses, considering the longitudinality and transversality of performances/ competences/contents.

It stands out a contribution to the identification of different variables and thematic categories for understanding the theme. This contribution makes it possible to understand and expand the insertion of the social dimension in the curricula giving visibility to the theme.

By using the instrument, other institutions can make adaptations according to the specificities of local realities, with diversity in public policies, epidemiological data, health needs, services offered, curricula of courses, habits and cultures. Despite these possible differences, the script presents some universal guidelines, relating to human beings, their social relations, cultural and environmental context. Thus, the same elements are usually important in training of physicians and other health professionals anywhere in the world.

Regarding the limitations, the presented study cannot be considered final. Investigations need be carried about the effectiveness of the SDAS as support for paper case construction, its handle and the results of student learning acquisition evaluation. There are also possibilities for further studies in other learning scenarios and in other institutions with different methodologies.

\section{Conflicts of Interest}

The authors declare no conflicts of interest regarding the publication of this paper.

\section{References}

Acosta, A. R., \& Vitale, M. A. F. (2015). Família: Redes, laços e políticas públicas (6th ed.). São Paulo: Cortez.

Andreasen, N. C., \& Black, D. W. (2008). Introdução à psiquiatria (4th ed.). São Paulo: Artmed.

Aquilante, A. G., Silva, R. F., Avó, L. R. S., Gonçalves, F. G. P., \& Souza, M. B. B. (2011). Situações-problema simuladas: Uma análise do processo de construção. Revista Brasileira de Educação Médica, 35, 147-156. https://doi.org/10.1590/S0100-55022011000200002

Bardin, L. (2012). Análise de conteúdo. São Paulo: Edições 70. 
Barroco, M. L. S. (2016). O que é preconceito? Brasília: Conselho Federal de Serviço Social.

Barros, N. F., \& Lourenço, L. C. A. (2006). O ensino da saúde coletiva no método de aprendizagem baseado em problemas: Uma experiência da Faculdade de Medicina de Marília. Revista Brasileira de Educação Médica, 30, 136-146. https://doi.org/10.1590/S0100-55022006000300004

Barrows, H. S., \& Tamblyn, R. M. (1980). Problem-Based Learning: An Approach to Medical Education. New York: Springer.

Bonin, L. F. R. (2008). Educação, consciência e cidadania. In Cidadania e participação social (pp. 92-104). Rio de Janeiro: Centro EdelsteinPesqui Soc. http://books.scielo.org/id/hn3q6/pdf/silveira-9788599662885-10.pdf

Brasil. Ministério do Desenvolvimento Social (2005). Política Nacional de Assistência Social/PNAS 2004. Brasília: Ministério do Desenvolvimento Social.

Brasileiro, T. O. Z., Souza, V. H. S., Prado, A. A. O., Lima, R. S., Nogueira, D. A. et al. (2017). Bem-estar espiritual e coping religioso/espiritual em pessoas com insuficiência renal crônica. Avances en Enfermería, 35, 159-170.

https://doi.org/10.15446/av.enferm.v35n2.60359

Campos, F. E., Aguiar, R. A. T., \& Belisário, A. S. (2012). A formação superior dos profissionais de saúde. In L. Giovanella, S. Escorel, L. V. C. Lobato, J. C. Noronha, \& A. I Carvalho (Eds.), Políticas e sistema de saúde no Brasil (2nd ed., pp. 885-932). Rio de Janeiro: Fiocruz.

Cavalcante, S. G. (2006). Entre a ciência e a reza: Estudo de caso sobre a incorporação das rezadeiras ao Programa Saúde da Família no município de Maranguape CE. Dissertação, Rio de Janeiro: Universidade Federal Rural do Rio de Janeiro.

Cecílio, L. C. O. (2009). As necessidades de saúde como conceito estruturante na luta pela integralidade e equidade na atenção em saúde. In R. Pinheiro, \& R. A. Mattos (Eds.), Os sentidos da integralidade na atenção e no cuidado à saúde (pp. 117-130, 8th ed.). Rio de Janeiro: ABRASCO.

Cecílio, L. C. O., \& Matsumoto, N. F. (2006). Uma taxonomia operacional de necessidades de saúde. In CEPESC (Ed.), Gestão em redes: tecendo os fios da integralidade em saúde (p. 8). Rio Janeiro: CEPESC.

Faculdade de Medicina de Marília (2012). O currículo da Famema Marília (SP). http://www.famema.br/ensino/cursos/docs/Texto_Curriculo_Medicina_2012.pdf

Faculdade de Medicina de Marília (2014). Projeto Pedagógico do curso de Medicina Marília (SP). http://www.famema.br/ensino/cursos/medicina.php

Fontes, M. B., Crivelaro, R. C., Scartezini, A. M., Lima, D. D., Garcia, A. A. et al. (2017). Fatores determinantes de conhecimentos, atitudes e práticas em DST/Aids e hepatites virais, entre jovens de 18 a 29 anos, no Brasil. Ciência \& Saúde Coletiva, 22, 1343-1352. https://doi.org/10.1590/1413-81232017224.12852015

Freire, P. (2015). Pedagogia da autonomia: Saberes necessários à prática educativa (50th ed.). Rio de Janeiro: Paz e Terra.

Freud, A. (2005). O ego e os mecanismos de defesa. São Paulo: Artmed.

Garbois, J. A., Sodré, F., \& Dalbello-Araujo, M. (2017). Da noção de determinação social à de determinantes sociais da saúde. Saúde debate, 41, 63-76.

https://doi.org/10.1590/0103-1104201711206

Garnelo, L., \& Pontes, A. L. (2012). Saúde Indígena: Uma introdução ao tema. Brasília: MEC-SECADI. https://doi.org/10.1590/S0104-59702011000100011

http://bvsms.saude.gov.br/bvs/publicacoes/saude_indigena_uma_introducao_tema.pdf 
Geertz, C. (2017). A interpretação das culturas. Rio de Janeiro: LTC.

Greer, J. R. P. J., Brown, D. R., Brewster, L. G., Lage, O. G., Esposito, K. F. et al. (2018). Socially Accountable Medical Education: An Innovative Approach at Florida International University Herbert Wertheim College of Medicine. Academic Medicine, 93, 60-65. https://doi.org/10.1097/ACM.0000000000001811

Jaramillo, A. N. M. (2018). Territorio, lugares y salud: Redimensionar lo espacial ensalud pública. Cadernos de Saúde Pública, 34, 12. https://doi.org/10.1590/0102-311x00075117

Jonassen, D. H., \& Hung, W. (2008). All Problems Are Not Equal: Implications for Problem-Based Learning. Interdisciplinary Journal of Problem-Based Learning, 2, 6-28. https://doi.org/10.7771/1541-5015.1080

Lei $\mathrm{n}^{\circ} 8.080$ de 19 de setembro de 1990 (1990). Dispóe sobre as condições para a promoção, proteção e recuperação da saúde, a organização e o funcionamento dos serviços correspondentes e dá outras providências. http://www.planalto.gov.br/ccivil_03/leis/L8080.htm

Lima, V. V. (2005). Competência: Distintas abordagens e implicações na formação de profissionais de saúde. Interface (Botucatu), 9, 369-379.

https://doi.org/10.1590/S1414-32832005000200012

Mamede, S., Penaforte, J., Schmidt, H., Caprara, A., Tomaz, J. B. et al. (2001). Aprendizagem baseada em problemas: Anatomia de uma nova abordagem educacional. Fortaleza: Hucitec.

Minayo, M. C. S., Figueiredo, A. E. B., \& Mangas, R. M. N. (2017). O comportamento suicida de idosos institucionalizados: Histórias de vida. Physis (Rio de Janeiro, Brazil), 27, 981-1002. https://doi.org/10.1590/s0103-73312017000400007

Missel, A., Costa, C. C., \& Sanfelice, G. R. (2017). Humanização da saúde e inclusão social no atendimento de pessoas com deficiência física. Trabeduc saúde, 15, 575-597. https://doi.org/10.1590/1981-7746-sol00055

Mota, S. (2013). Saúde ambiental. In M. Z. S. Rouquayrol, \& M. G. C. Rouquayrol (Eds.), Epidemiologia \& saúde (pp. 383-399, 7th ed.). Rio Janeiro: MedBook.

Portaria $n^{\circ}$ 793, de 24 de abril de 2012 (2012). Institui a Rede de Cuidados à Pessoa com Deficiência no âmbito do Sistema Único de Saúde. http://bvsms.saude.gov.br/bvs/saudelegis/gm/2012/prt0793_24_04_2012.html

Rabelo, L. D. B. C., Silva, J. M. A., \& Lima, M. E. A. (2018). Trabalho e adoecimento psicossomático: Reflexões sobre o problema do nexo causal. The Psicologia Ciência e Profissão, 38, 116-128. https://doi.org/10.1590/1982-3703000932017

Resolução CNE/CES n 3 de junho de 2014 (2014). Institui Diretrizes Curriculares Nacionais do Curso de Graduação em Medicina e dá outras providencias. http://portal.mec.gov.br/index.php?option=com_docman\&view=download\&alias $=158$ 74-rces003-14\&category_slug=junho-2014-pdf\&Itemid=30192

Rocha, R. (2016). Racismo. Brasília: Conselho Federal de Serviço Social.

Rückert, B., Cunha, D. M., \& Modena, C. M. (2018). Saberes e práticas de cuidado em saúde da população do campo: Revisão integrativa da literatura. Interface (Botucatu), 22, 903-914. https://doi.org/10.1590/1807-57622017.0449

Sales, M. A., Matos, M. C., \& Leal, M. C. (2015). Política social: Família e juventude: Uma questão de direitos. São Paulo: Cortez.

Sampaio, J. J. C., Guimarães, J. M. X., \& Sampaio, A. M. (2013). Saúde mental. In M. Z. S. Rouquayrol, \& M. G. C. Rouquayrol (Eds.), Epidemiologia \& saúde (7th ed., pp. 423-446). Rio Janeiro: MedBook. 
Segheto, W., Hallal, P. C., Marins, J. C. B., Silva, D. C. G., Coelho, F. A. et al. (2018). Fatores associados e índice de adiposidade corporal (IAC) em adultos: Estudo de base populacional. Ciência \& Saúde Coletiva, 23, 773-783. https://doi.org/10.1590/1413-81232018233.11172016

Silva, J. R. S., Almeida, C. D., \& Guindani, J. F. (2009). Pesquisa documental: Pistas teóricas e metodológicas. Revista Brasileira de História \& Ciências Sociais, 1, 1-15.

Siqueira, D. P., \& Castro, L. R. B. (2017). Minorias e grupos vulneráveis: A questão terminológica como fator preponderante para uma real inclusão social. Revista Direitos Sociais e Políticas Públicas, 5, 105-122. https://doi.org/10.25245/rdspp.v5i1.219

http://www.unifafibe.com.br/revista/index.php/direitos-sociais-politicas-pub/article/vi ew/219/pdf

Skinner, B. E. (1953). Science and Human Behavior. New York: Macmillan.

Souza, A. M. M., \& Ciampa, A. C. (2017). Devemos Continuar? Identidade, história e utopia do educador de rua. Psicologia \& Sociedade, 29, e171957.

https://doi.org/10.1590/1807-0310/2017v29171957

Souza, V. B. (2014). Gênero, marxismo e serviço social. Temporalis, 14, 13-31. http://publicacoes.ufes.br/temporalis/article/download/7429/5848

Stewart, M., Brown, J. B., Weston, W. W., Whinney, I. R. M., William, C. L. M. et al. (2010). Medicina centrada na pessoa: Transformando o método clínico. Porto Alegre: Artmed.

Teixeira, C. F., Paim, J. S., \& Vilasbôas, A. L. (2000). SUS, modelos assistenciais e vigilância da saúde. In FIOCRUZ (Ed.), Fundamentos da vigilância sanitária (pp. 49-60). Rio Janeiro: Fiocruz.

Thomas, B. (2014). Health and Health Care Disparities: The Effect of Social and Environmental Factors on Individual and Population Health. International Journal of Environmental Research and Public Health, 11, 7492-7507. https://doi.org/10.3390/ijerph110707492

Toniol, R. (2017). O que faz a espiritualidade? Religião \& Sociedade, 37, 144-175. https://doi.org/10.1590/0100-85872017v37n2cap06

Torres, T. L., Camargo, B. V., Boulsfield, A. B., \& Silva, A. O. (2015). Representações sociais e crenças normativas sobre envelhecimento. Ciência \& Saúde Coletiva, 20, 3621-3630. https://doi.org/10.1590/1413-812320152012.01042015

Vasconcelos, A. C. F., Stedefeldt, E., \& Frutuoso, M. F. P. (2016). Uma experiência de integração ensino-serviço e a mudança de práticas profissionais: Com a palavra, os profissionais de saúde. Interface (Botucatu), 20, 147-158. https://doi.org/10.1590/1807-57622015.0395

World Health Organization (1996). Global Consultation on Violence and Health. Violence: A Public Health Priority. Geneva: WHO.

World Health Organization (2003). Adherence to Long-Term Therapies: Evidence for Action. Geneva: WHO. http://www.who.int/chp/knowledge/publications/adherence_report/en

Zanella, D. C. (2018). Humanidades e ciência: Uma leitura a partir da bioética de Van Rensselaer (V. R.) Potter. Interface (Botucatu), 22, 473-480. https://doi.org/10.1590/1807-57622016.0914

Zerbetto, S. R., Gonçalves, A. M. S., Santile, N., Galera, S. A. F., Acorinte, A. C. et al. (2017). Religiosidade e espiritualidade: Mecanismos de influência positiva sobre a vida e tratamento do alcoolista. Escola Anna Nery Revista de Enfermagem, 21, 8. https://doi.org/10.5935/1414-8145.20170005 